\title{
Uranium Loss from Biso-Coated Weak-Acid-Resin HTGR Fuel
}

\author{
R. L. Pearson \\ T. B. Lindemer
}




\section{DISCLAIMER}

This report was prepared as an account of work sponsored by an agency of the United States Government. Neither the United States Government nor any agency Thereof, nor any of their employees, makes any warranty, express or implied, or assumes any legal liability or responsibility for the accuracy, completeness, or usefulness of any information, apparatus, product, or process disclosed, or represents that its use would not infringe privately owned rights. Reference herein to any specific commercial product, process, or service by trade name, trademark, manufacturer, or otherwise does not necessarily constitute or imply its endorsement, recommendation, or favoring by the United States Government or any agency thereof. The views and opinions of authors expressed herein do not necessarily state or reflect those of the United States Government or any agency thereof. 


\section{DISCLAIMER}

Portions of this document may be illegible in electronic image products. Images are produced from the best available original document. 


\section{Printed in the United States of America. Available from}

National Technical Information Service

U.S. Department of Commerce

5285 Port Royal Road, Springfield, Virginia 22161

Price: Printed Copy $\$ 4.00$; Microfiche $\$ 3.00$

This report was prepared as an account of work sponsored by the United States Government. Neither the United States nor the Energy Research and Development Administration/United States Nuclear Regulatory Commission, nor any of their employees, nor any of their contractors, subcontractors, or their employees, makes any warranty, express or implied, or assumes any legal liability or responsibility for the accuracy, completeness or usefulness of any information, apparatus, product or process disclosed, or represents that its use would not infringe privately owned rights. 
Contract No. W-7405-eng-26

CHEMICAL TECHNOLOGY DIVISION

HTGR BASE TECHNOLOGY PROGRAM

Fuel Chemistry Studies (189a 01329)

URANIUM LOSS FROM BISO-COATED WEAK-ACID-RESIN HTGR FUEL

R. L. Pearson

T. B. Lindemer

Date Published: February 1977

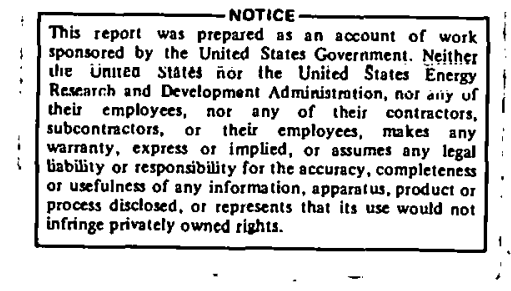

OAK RIDGE NATIONAL LABORATORY

Oak Ridge, Tennessee 37830

operated by

UNION CARBIDE CORPORATION

for the

ENERGY RESEARCH AND DEVELOPMENT ADMINISTRATION 
THIS PAGE

WAS INTENTIONALLY

LEFT BLANK 
TABLE OF CONTENTS

$\underline{\text { Page }}$

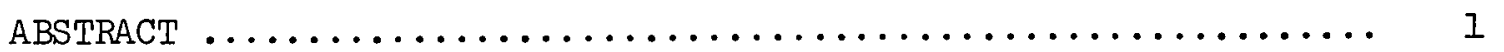

1. INTRODUCTION $\ldots \ldots \ldots \ldots \ldots \ldots \ldots \ldots \ldots \ldots \ldots \ldots \ldots \ldots \ldots \ldots \ldots$

2. EXPERTMENTAL PROCEDURE $\ldots \ldots \ldots \ldots \ldots \ldots \ldots \ldots \ldots \ldots \ldots \ldots \ldots$

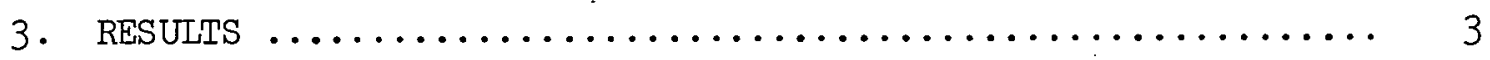

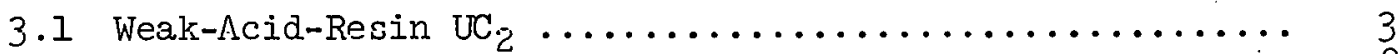

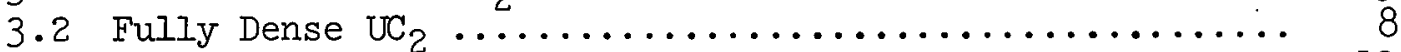

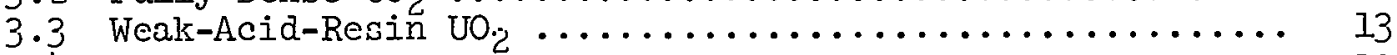

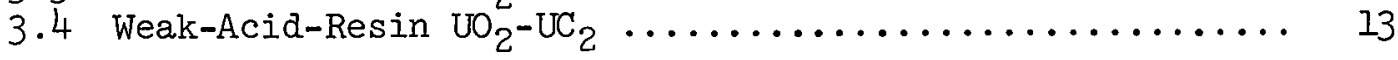

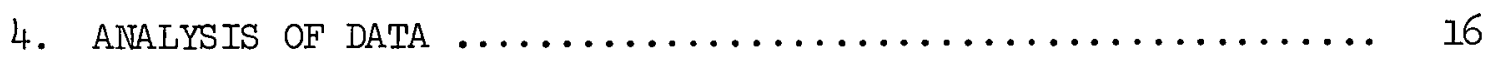

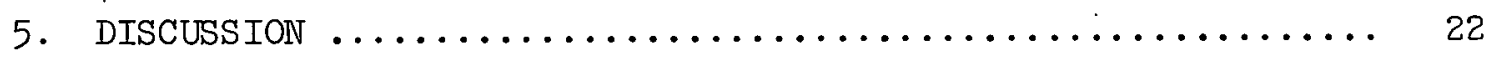

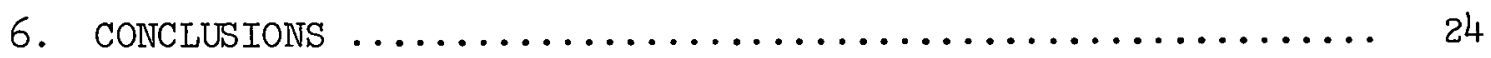

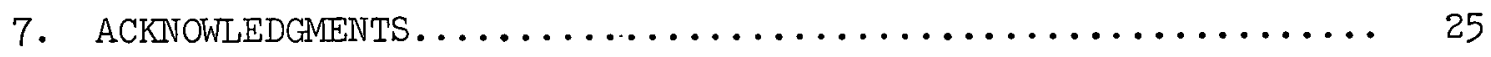

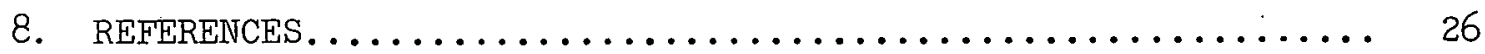


URAIVIUM LOSS FROM BISO-COATED WEAK-ACID-RESTIN HTGR FUEI

R. L. Pears on and T. B. Lindemer

ABSTRACT

Recycle fuel for the High-Temperature Gas-Cooled Reactor (HTGR) contains a weak-acid-resin (WAR) kernel, which consists of a mixture of $\mathrm{UC}_{2}, \mathrm{UO}_{2}$, and free carbon. At $1900^{\circ} \mathrm{C}$, BISO-coated WAR $\mathrm{UC}_{2}$ or $\mathrm{UC}_{2}-\mathrm{UO}_{2}$ kernels lose a significant portion of their uranium in several hundred hours. The $\mathrm{UC}_{2}$ decomposes and uranium diffuses through the pyrolytic coating. The rate of escape of the uranium is dependent on the temperature and the surface area of the $\mathrm{UC}_{\boldsymbol{z}}$, but not on a temperature gradient. The apparent activation energy for uranium loss, $\Delta H$, is $\sim 90$ $\mathrm{kcal} / \mathrm{mole}$. Calculations indicate that uranium loss from the kernel would be insignificant under conditions to be expected in an HTGR.

\section{INTRODUCTION}

During 1974, a decision was made to change the reference recycle fuel for the High-Temperature Gas-Cooled Reactor (HTGR). A weak-acidresin (WAR) rissile kernel containing a mixture of $\mathrm{UC}_{2}$ and $\mathrm{UO}_{2}$ was selected because of its superior irradiation performance. ${ }^{1}$ This report discusses some properties of WAR particles, especially their potential to looc uranium when $\mathrm{UC}_{2}=$ onlinining purticles are exposed to high temperatures for long periods of time.

\section{EXPERIMEITAL PROCEDURE}

All of the kernels used in this study were prepared from weak-acid resins. The characteristics of the particles are given in Table 1 . About 50 particles from each batch were mounted in a carbon disc and heat-treated in a graphite-resistance furnace where a known temperature and temperature gradient were maintained. The details of the procedure used to prepare particles for heat treatment have been published previously. ${ }^{2}$ Particle 
Table 1. Characterization 0 : WAR coajed parjicles preparec for use in studies of uranium loss

\begin{tabular}{|c|c|c|c|c|c|}
\hline $\begin{array}{l}\text { Coated particle } \\
\text { Batch number } \\
\text { Percent conversion } \\
\text { Uranium content, wt. \% }\end{array}$ & $\begin{array}{l}\text { OR-2215 } \\
0 \\
15.55\end{array}$ & $\begin{array}{l}A-599 \\
69.4 \pm 2.1 \\
17.32\end{array}$ & $\begin{array}{l}\text { OR-212O-H } \\
92 \\
23.66\end{array}$ & $\begin{array}{l}\text { OR- }-\approx \approx 38-H \\
\sim 1 C \mathrm{C} \\
23 \cdot \mp \tau\end{array}$ & $\begin{array}{l}\text { OR-2121-H } \\
92 \\
20.03\end{array}$ \\
\hline & Nean $^{z}$ & $\operatorname{Mean}^{\mathrm{a}}$ & $\operatorname{Mean}^{\mathrm{a}}$ & Mie:an ${ }^{a}$ & $\operatorname{Mean}^{\mathrm{a}}$ \\
\hline $\begin{array}{l}\text { Kernel. } \\
\text { Diameter, } \mu \mathrm{m} \\
\text { Densit } \mathrm{g}, \mathrm{g} / \mathrm{cm}^{3}\end{array}$ & $\begin{array}{l}371.3 \\
3.66\end{array}(15.4)$ & $\begin{array}{c}354.2(15.9) \\
3.034\end{array}$ & $\begin{array}{l}315.3(29.1) \\
5.28\end{array}$ & $\begin{array}{l}340.9(19.9) \\
3.27\end{array}$ & $\begin{array}{l}315.3(29.1) \\
5.28\end{array}$ \\
\hline $\begin{array}{l}\text { Buffer lajer } \\
\text { Thickness, } \mu \mathrm{m}\end{array}$ & $59.3(9.8)$ & $58.8(9.4)$ & $7+.9(11.3)$ & 8.1. & $74.6(11.3)$ \\
\hline $\begin{array}{c}\text { Inner carbon coating } \\
\text { Thickness, } \mu \mathrm{m}\end{array}$ & & & & & $36.1(3.8)$ \\
\hline $\begin{array}{l}\text { SiC layer } \\
\text { Thickness, } \mu \mathrm{m}\end{array}$ & . & $\cdot$ & & & $28.4(2.7)$ \\
\hline $\begin{array}{l}\text { Outer carbon coating } \\
\text { Thickness, } \mu \mathrm{m}\end{array}$ & $42.0(3.0)$ & $35.4(3.5)$ & $88.6(6.6)$ & $62.3(3.6)$ & $49.2(3.3)$ \\
\hline
\end{tabular}

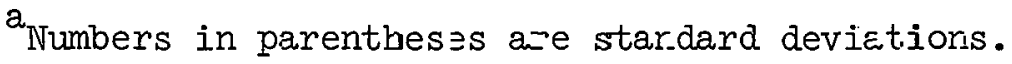


position and changes in kernel diameter were determined from radiographs of the mounted discs taken before and after heating. In this report, kernel diameter is defined as the diameter of the uranium-containing portion of the WAR kernel; the original diameter of the entire WAR kernel did not change with heat treatment. Uranium contents within the particles were obtained by microprobe analysis of a metallographic specimen; the uranium content is defined here relative to the uranium content in ascoated kernels from the same batch.

\section{RESULTS}

\subsection{Weak-Acid-Resin $\mathrm{UC}_{2}$}

Two discs containing BISO-coated. WAR kernels which had been essentially fully converted to $\mathrm{UC}_{2},{ }^{3}$ batch numbers $\mathrm{OR}-2120-\mathrm{H}$ and $\mathrm{OR}-2288-\mathrm{H}$, were heat-treated at a maximum temperature of $1940^{\circ} \mathrm{C}$ in a $278^{\circ} \mathrm{C} / \mathrm{cm}$ gradient. Radiographs of the discs were taken as prepared and after 143, 365, and $551 \mathrm{hr}$ in the furnace. The kernel diameters decreased, the rate depending on the temperature of the individual particles. Shrinkage of the kernels could be detected in particles heat-treated at temperatures as low as $1700^{\circ} \mathrm{C}$. One of the particles heated at $1900^{\circ} \mathrm{C}$ had no kernel remaining after $551 \mathrm{hr}$, as can be seen in Fig. 1.

Two particles, Nos. 22 and 23 of batch OR-2288-H, which had been held at $1800^{\circ} \mathrm{C}$ for $551 \mathrm{hr}$, were photographed after metallographically polishing one of the discs. The results revealed that the structure of the resin kernel was intact in each case and that little or no densification had occurred; however, there was a distinct, observable boundary line within the resin kernel. The diameter of the section enclosed by the boundary was the same as that of the uranium-bearing portion of the kernel, as observed in the radiograph. Particles 22 and 23 were also submitted for microprobe analysis. Backscattered electron and $\mathrm{UM}_{\alpha} \mathrm{x}$-ray intensity images were prepared. Photographs depicting the results of four types of analyses on the two particles are shown in Figs. 2 and 3 respectively. Microprobe data for both particles, as well as for ten as-coated archive particles chosen at random from batch $\mathrm{OR}-2288-\mathrm{H}$, are plotted in Fig. 4. Step scans were 

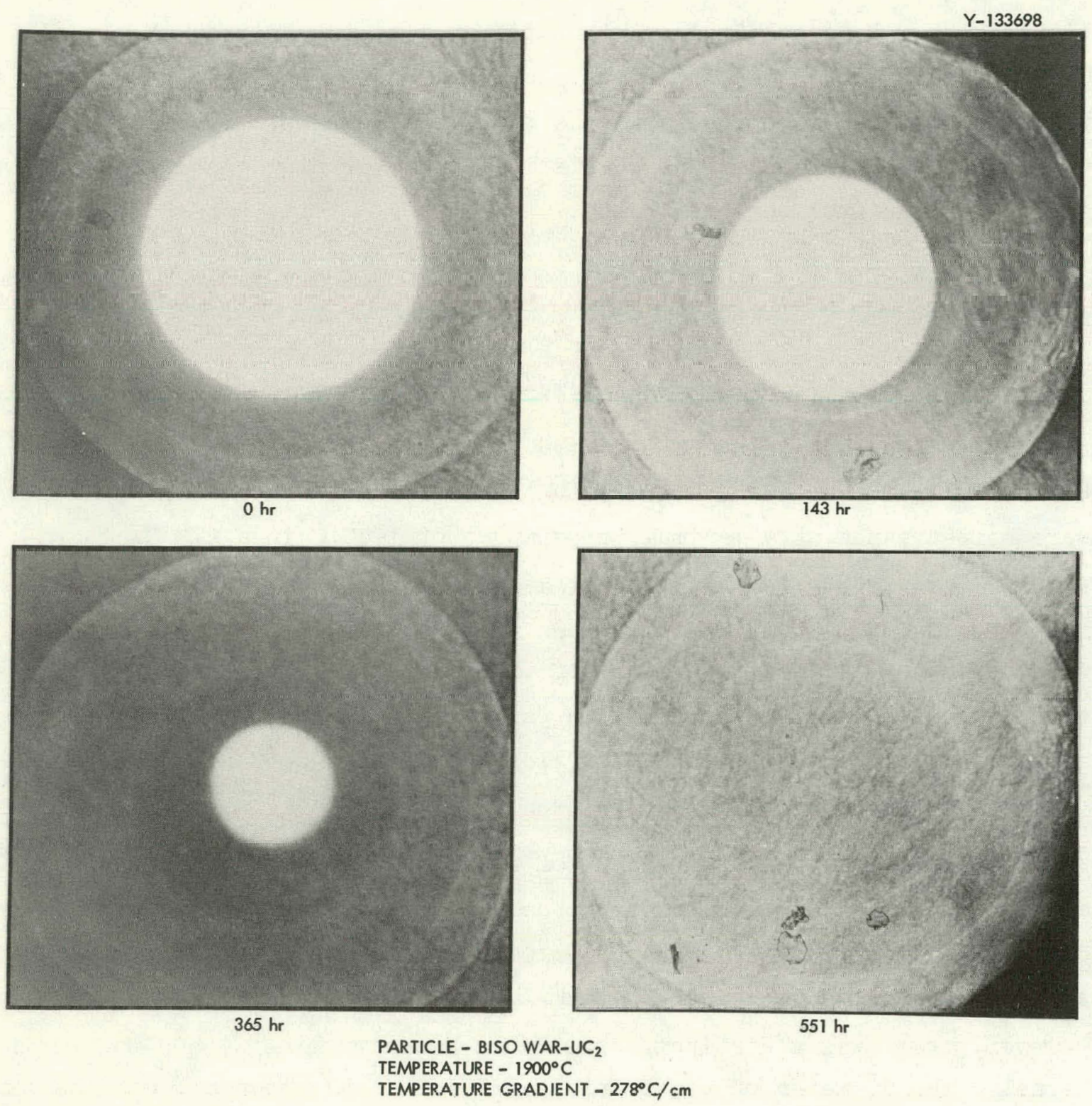

Fig. 1. Radiographs of a BISO-coated WAR UC ${ }_{2}$ particle heat-treated at $1900^{\circ} \mathrm{C}$ for various times. 


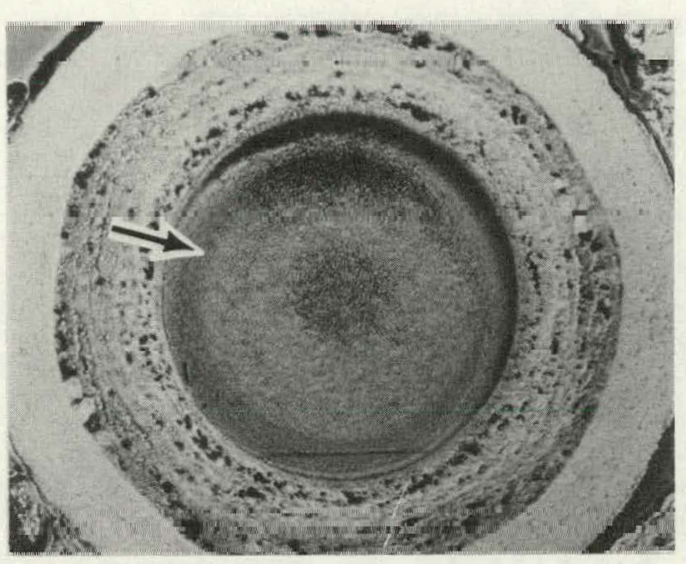

OPTICAL

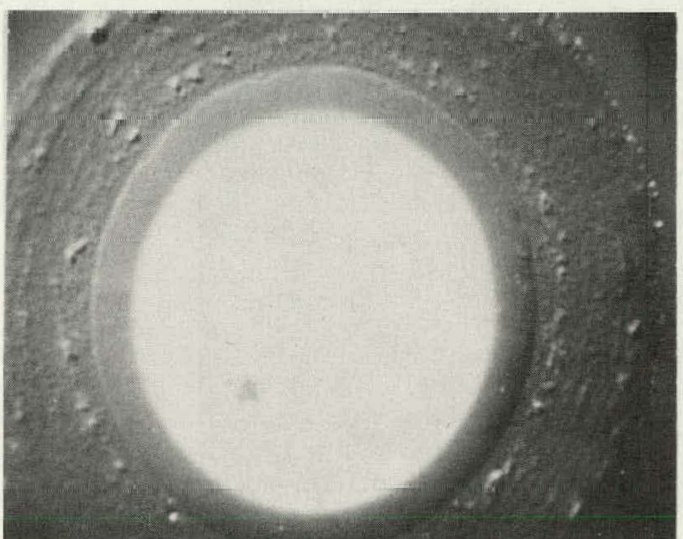

BACKSCATTERED ELECTRONS

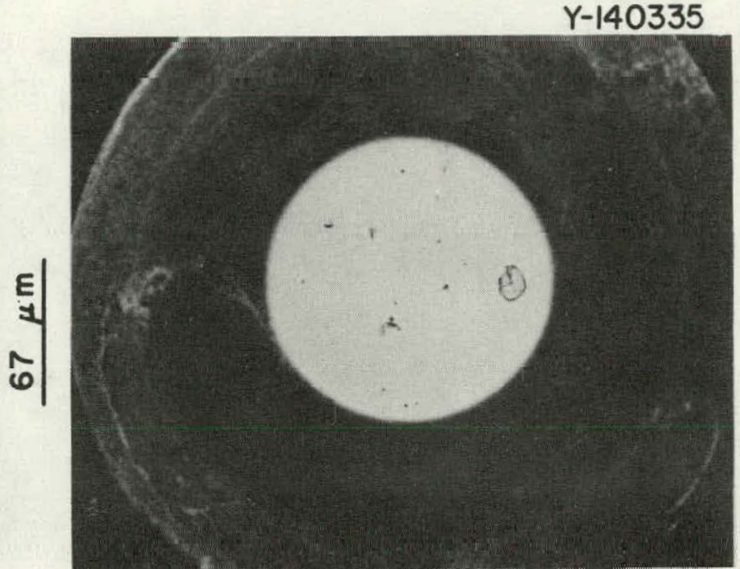

RADIOGRAPH

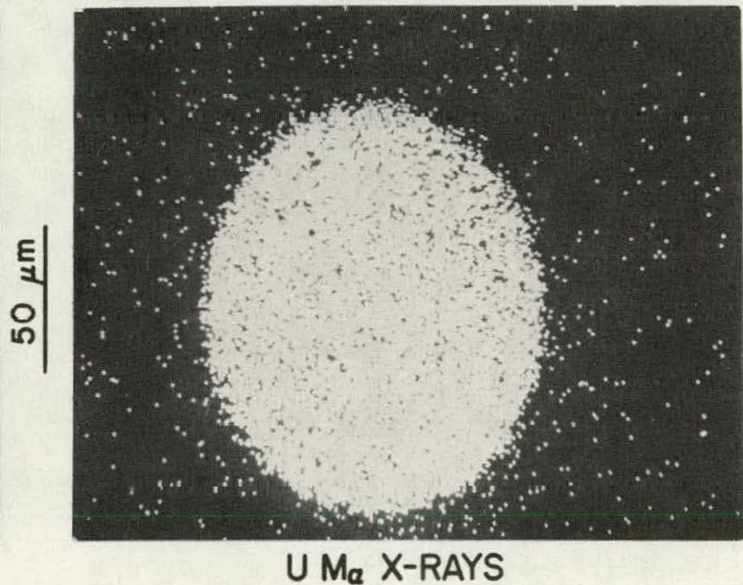

Fig. 2. Uranium distribution in BISO-coated WAR $\mathrm{UC}_{2}$ fuel particle 22, which had been heat-treated at $1800^{\circ} \mathrm{C}$ for $551 \mathrm{hr}$. The arrow points to the retreating $\mathrm{UC}_{2}$ interface.

Increasing

temperature

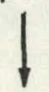




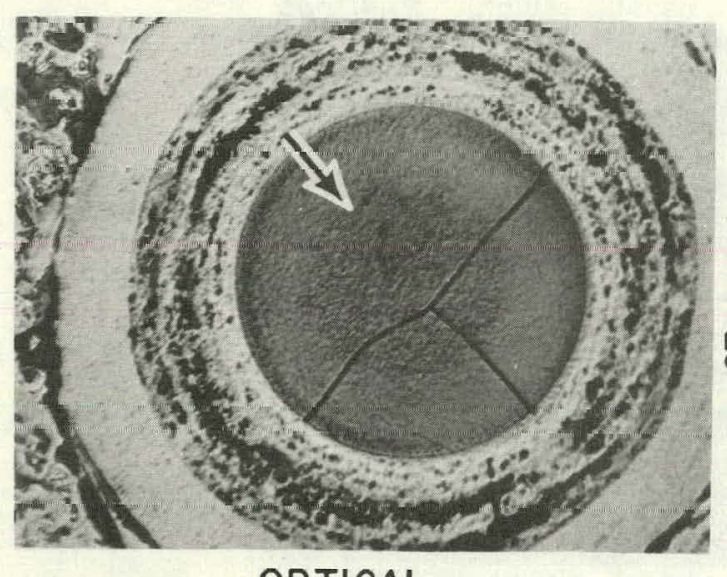

OPTICAL

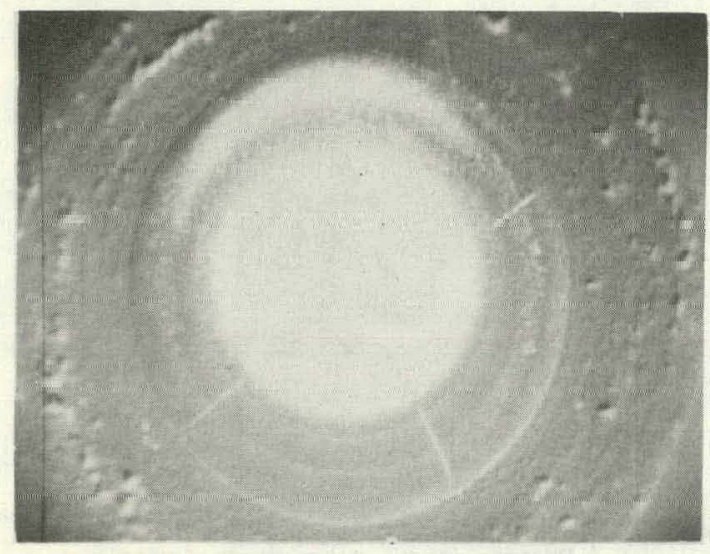

BACKSCATTERED ELECTRONS
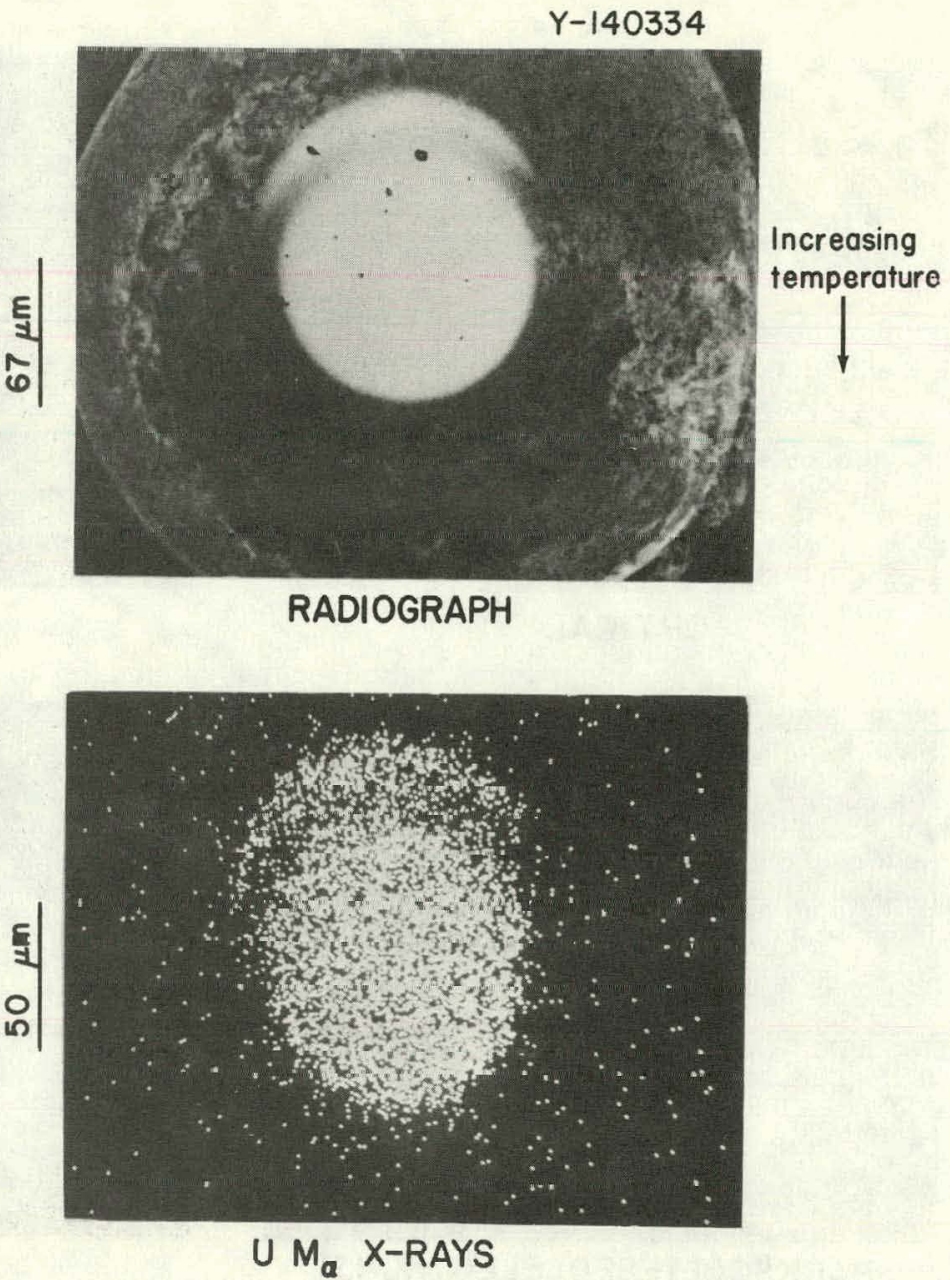

Fig. 3. Uranium distribution in BISO-coated WAR $\mathrm{UC}_{2}$ fuel particle 23, which had been heat-treated at $1800^{\circ} \mathrm{C}$ for $551 \mathrm{hr}$. 'l'he arrow points to the retreating $\mathrm{UC}_{2}$ interfuce. 
ORNL DWG. 75-8782

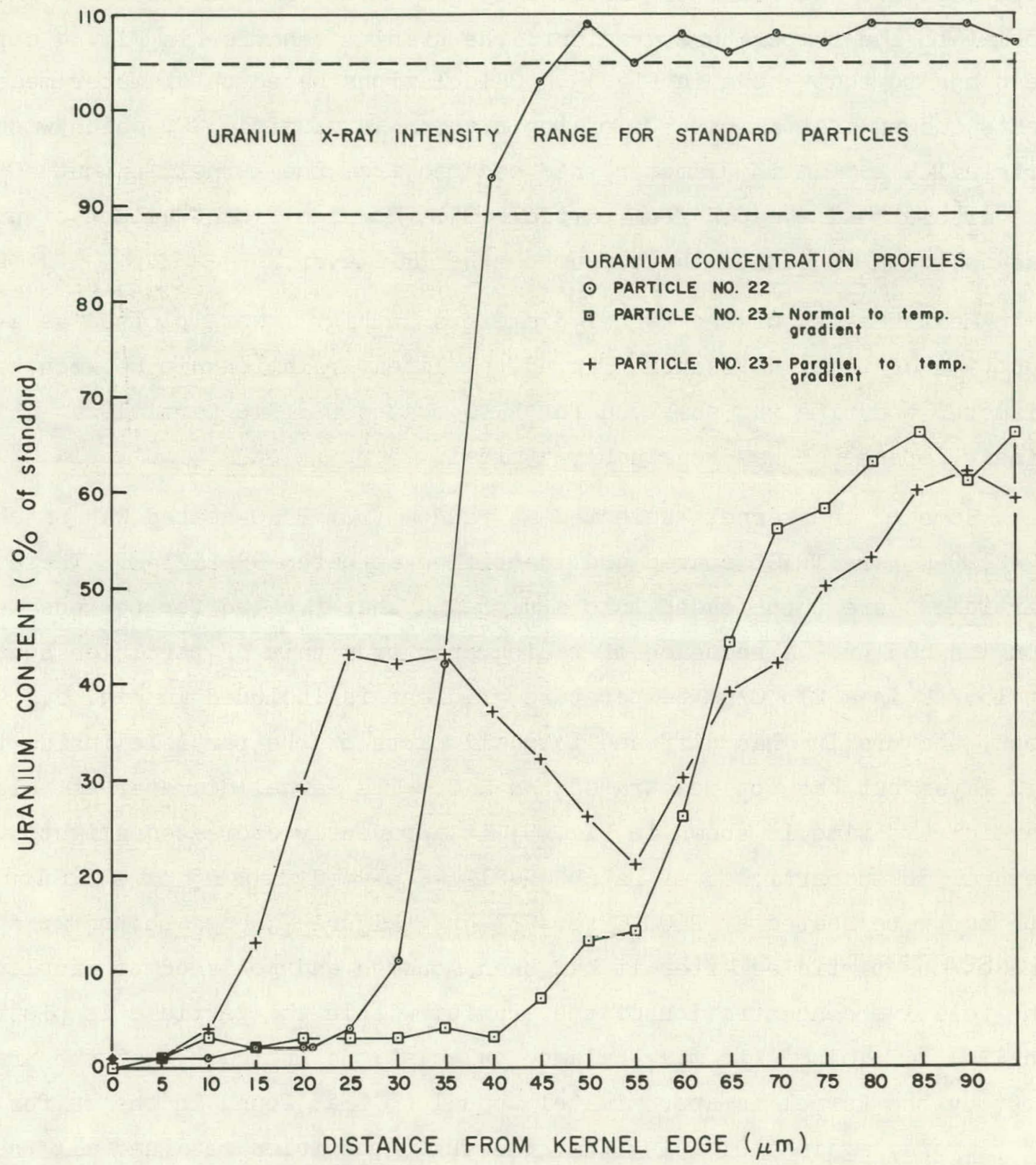

Fig. 4. Uranium content in BISO-coated WAR UC ${ }_{2}$ kernels heat-treated at $1800^{\circ} \mathrm{C}$ for $551 \mathrm{hr}$ vs distance from original edge of kernel. 
taken every $5 \mu \mathrm{m}$ along $100 \mu \mathrm{m}$ of the outer radius of the kernels in particles 22 and 23. Each kernel had little uranium present in the outer portion, and the uranium loss often appeared to be occurring in a $15-\mu \mathrm{m}-$ wide region. Two scans of particle 23 were made, one parallel and one normal to the temperature gradient; the uranium behavior in Fig. 4 corresponds to that shown in Fig. 3. Calculations based on diameter measurements showed that almost 50\% of the uranium in particle 22, which was originally $365 \mu \mathrm{m}$ in diameter, had escaped from the kernel. About $80 \%$ of the uranium had escaped from particle 23. No significant amount of uranium was detected in either the buffer $n r$ the ITI layer.

Medsurements of the kerne $\perp$ diameters in Fig. I were plotted as a function of time, as seen in Fig. 5. A linnar relationship betwcon licrnel diameter and time was observed for BISO-coated $\mathrm{UC}_{2}$ WAR particles. This linear dependence was reasonably typical.

Some of the kernels selected at random from BISO-coated WAR batch OR-2120-H were TRISO coated and identified as batch OR-2I2I-H. These particles were then loaded into a disc and heat-treated for periods as long as $665 \mathrm{hr}$. A sequence of radiographs of a pair of particles heated at $1862^{\circ} \mathrm{C}$ in a $2^{\prime}\left(8^{\circ} \mathrm{C} / \mathrm{cm}\right.$ temperature gradient is included in Fig. 6. As seen, the uranium has diffused into all parts of the particle inside the SiC layer but has not penetrated the SiC. The kernel diameter of this particle vs time is shown in Fig. 5; it apparently decreased slightly. Several dozen particles of batch OR-2121-H placed loosely in a hollow carbon rod were heated at $2100^{\circ} \mathrm{C}$ for $233 \mathrm{hr}$. Figure 7 shows photographs of one of the particles after it had been mounted and polished to midplane. The relative concentration of the uranium within the particlc is plotted in Fig. 8. Volumetric mass-balance calculations indicate that the uranium lost by the kernel is approximately equal to that form in the buffer and ITI layers, again indicating that the TRISO particles retained all the original uranium content.

\subsection{Fully Densc UC,}

BISO-coated, fully dense $\mathrm{UC}_{2}$ kernels were heated in the same discs that contained the WAR $\mathrm{UC}_{2}$ particles. Shrinkage of the fully dense $\mathrm{UC}_{2}$ kernels was never observed. 


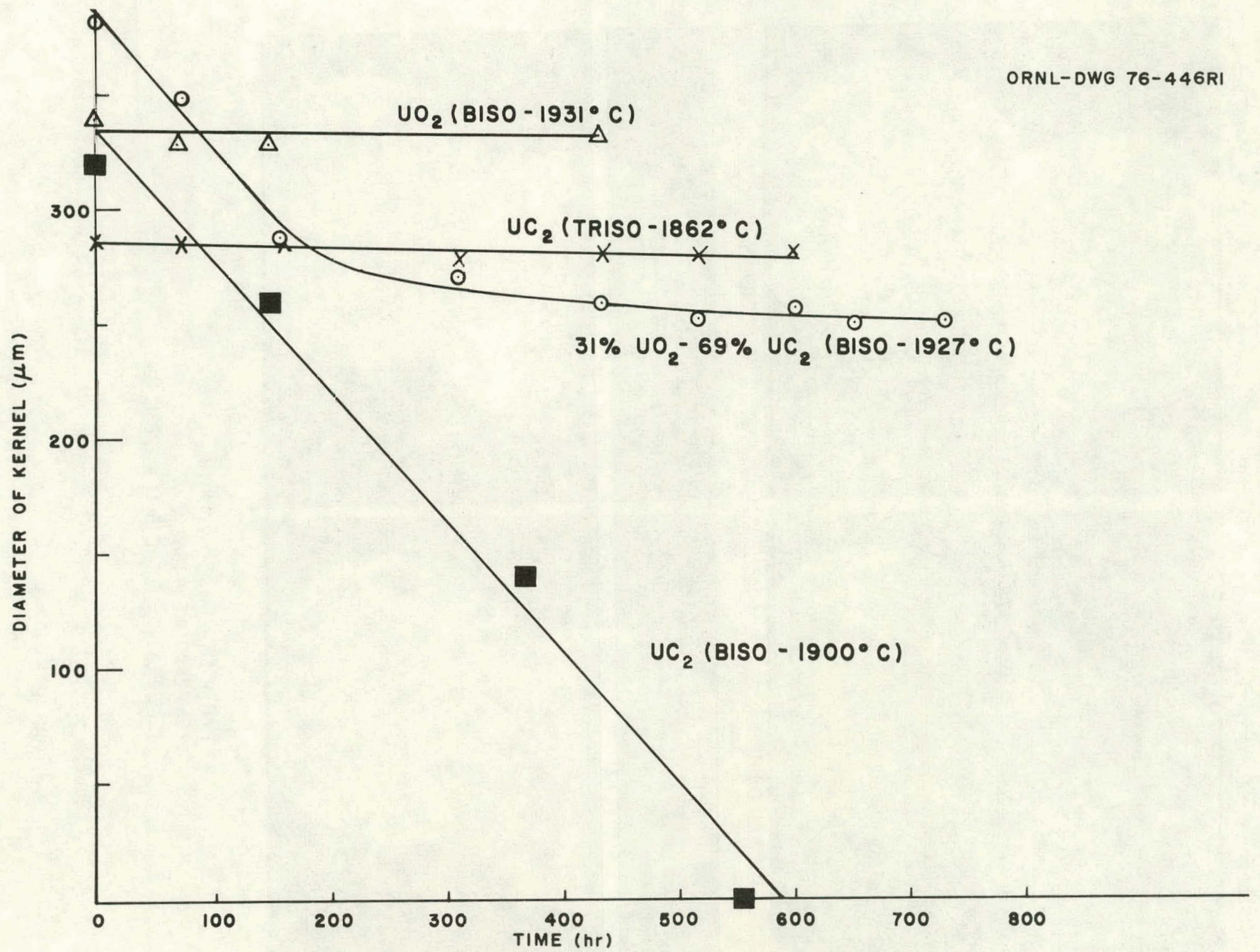

Fig. 5. Kernel diameters vs time for various WAR particles heattreated at the specified temperatures. 

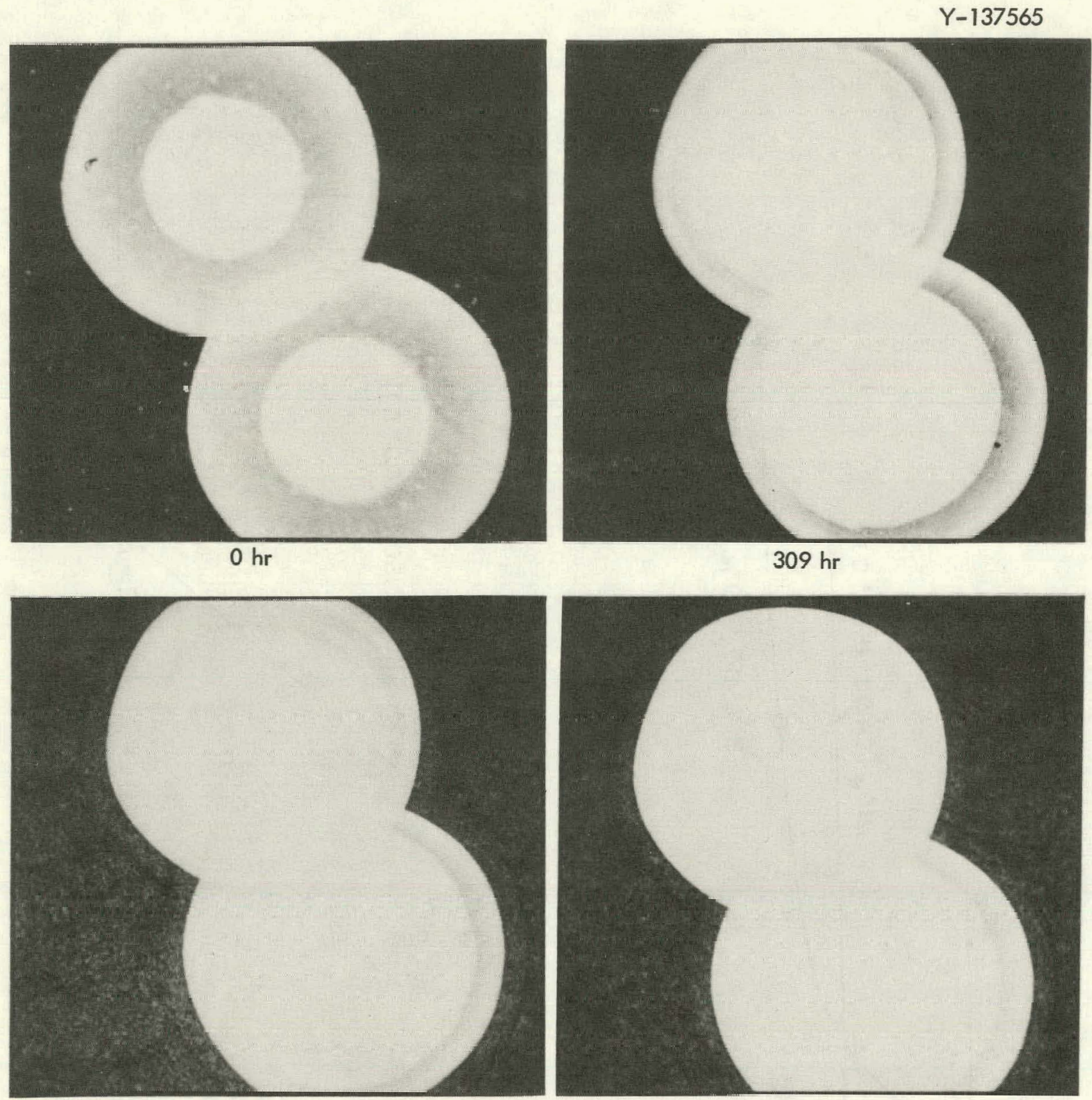

$582 \mathrm{hr}$

$665 \mathrm{hr}$

PARTICLE - TRISO WAR - UC 2

TEMPERATURE - $1862^{\circ} \mathrm{C}$

TEMPERATURE GRADIENT $-278^{\circ} \mathrm{C} / \mathrm{cm}$

Fig. 6. Radiographs of a TRISO-coated WAR UC ${ }_{2}$ particle heat-treated at $1862^{\circ} \mathrm{C}$ for various periods. 


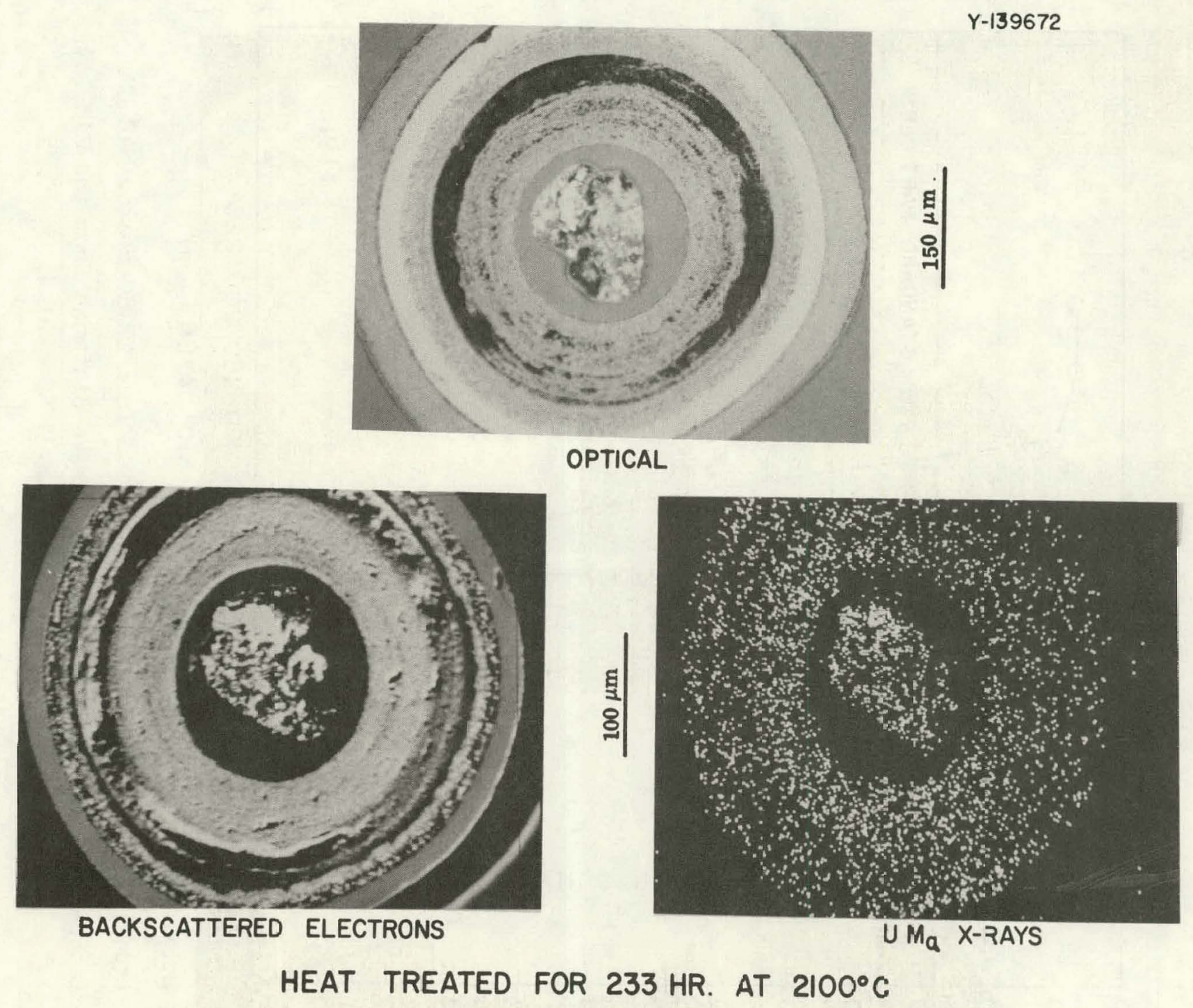

Y-139672

Fig. 7. Jranium redistribution in a TRISO-coated WAR UC 2 particle heat-treated at $2100^{\circ} \mathrm{C}$ for $233 \mathrm{hr}$. 
ORNL DWG $76-\mid 48$ IRI

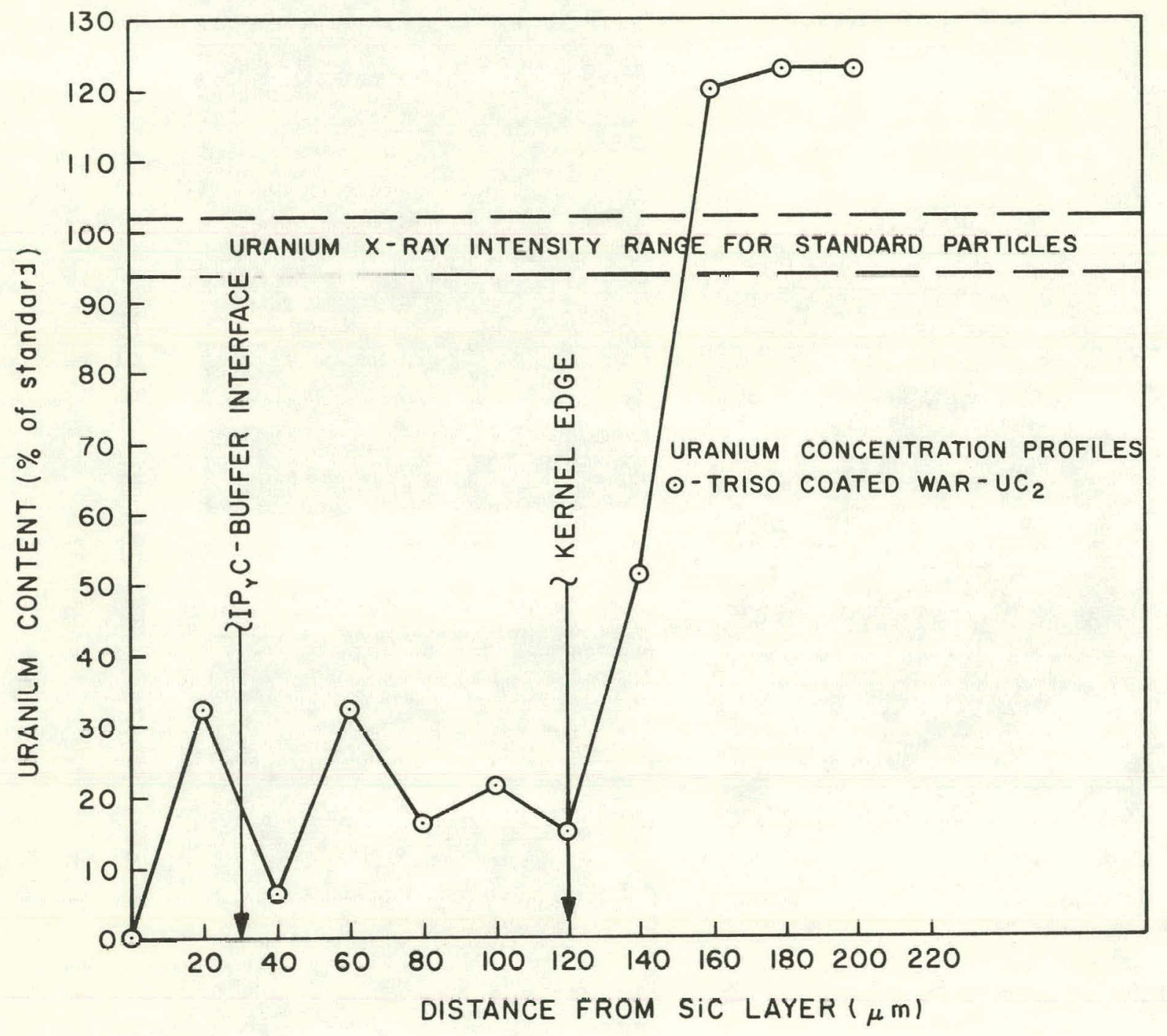

Fig. 8. Relative uranium concentration in a TRISO-coated WAK UL' particle heat-treated at $2100^{\circ} \mathrm{C}$ for $233 \mathrm{hr}$ vs distance from the SiC layer. 


\subsection{Weak-Acid-Resin $\mathrm{UO}_{2}$}

The diameters of BISO-coated. WAR $\mathrm{UO}_{2}$ kernels held at $1931^{\circ} \mathrm{C}$ for $435 \mathrm{hr}$ in a $278^{\circ} \mathrm{C} / \mathrm{cm}$ temperature gradient were unchanged, as shown in Fig. 5. There was no redistribution of uranium within the particle.

\subsection{Weak-Acid-Resin $\mathrm{UO}_{2}-\mathrm{UC}_{2}$}

A disc containing BISO-coated WAR kernels of the composition $31 \% \mathrm{UO}_{2}^{--}$ $69 \% \mathrm{UC}_{2}$ (batch A-599) was heated for as long as $730 \mathrm{hr}$ at a maximum temperature of $1927^{\circ} \mathrm{C}$ in a $278^{\circ} \mathrm{C} / \mathrm{cm}$ gradient. The initial rate of decrease of kernel diameter at $1927^{\circ} \mathrm{C}$ was the same as that for a $100 \% \mathrm{UC}_{2}$ kernel up to $\sim 200 \mathrm{hr}$, when the rate of kernel shrinkage began to decrease. The diameter of a kernel heated at $1927^{\circ} \mathrm{C}$ decreased up to $582 \mathrm{hr}$ but then remained essentially constant with further heating. Radiographs of this particle are shown in Fig. 9. The final uranium-containing volume was $\sim 30 \%$ of the original kernel volume. This strongly suggests that the $\mathrm{UC}_{2}$ was lost, leaving only the original $\mathrm{UO}_{2}$ content. It also suggests that the WAR conversion of $\mathrm{UO}_{2}$ to $\mathrm{UC}_{2}$ during kernel manufacture proceeds from the outside to the inside of the kernel.

All of the uranium associated with $\mathrm{UC}_{2}$ within a loose sample of these $31 \% \mathrm{UO}_{2}--69 \% \mathrm{UC}_{2}$ particles was lost when they were held at a uniform, constant temperature of $2100^{\circ} \mathrm{C}$ for $325 \mathrm{hr}$. Therefore, the mechanism for uranium loss is not dependent on a temperature gradient.

An examination of the radiographs for some of the particles in the disc revealed interesting characteristics of the uranium loss (see Fig. 10). Sufficient uranium collected in the buffer layer on the hotter side during the initial heat-treating times to be detected in the radiographs; however, this buffer-layer uranium content was gradually lost with time, as illustrated. The outside of the kernel develops a lower content of uranium than the central portion, and an interface between the two regions can therefore be detected in the radiographs. This in-kernel effect can be seen in Fig. 9 at $73 \mathrm{hr}$; here, because of a higher temperature, the uranium loss is in a more advanced stage. The central uranium-containing portion also develops a tendency to become located off-center relative to the original 


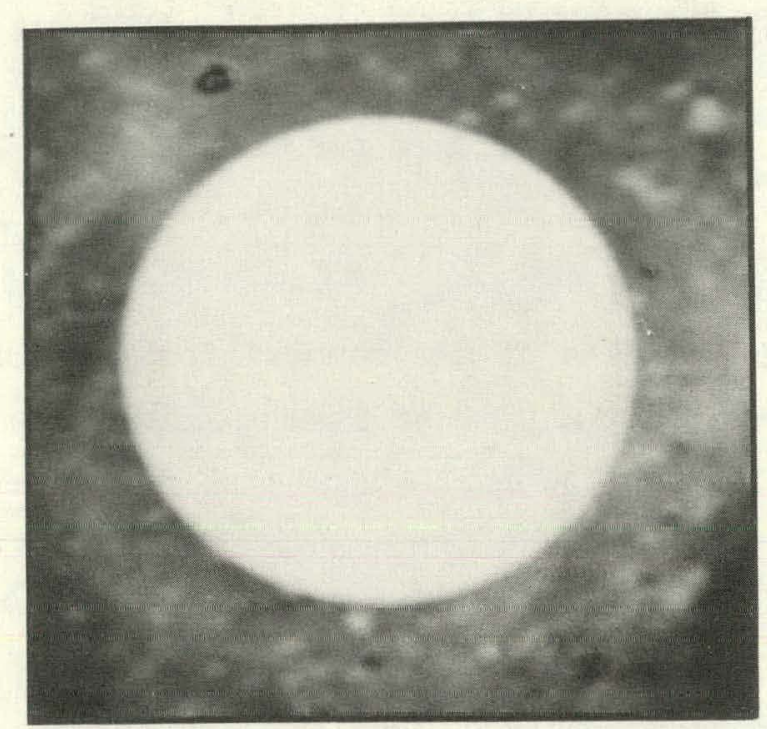

$0 \mathrm{hr}$

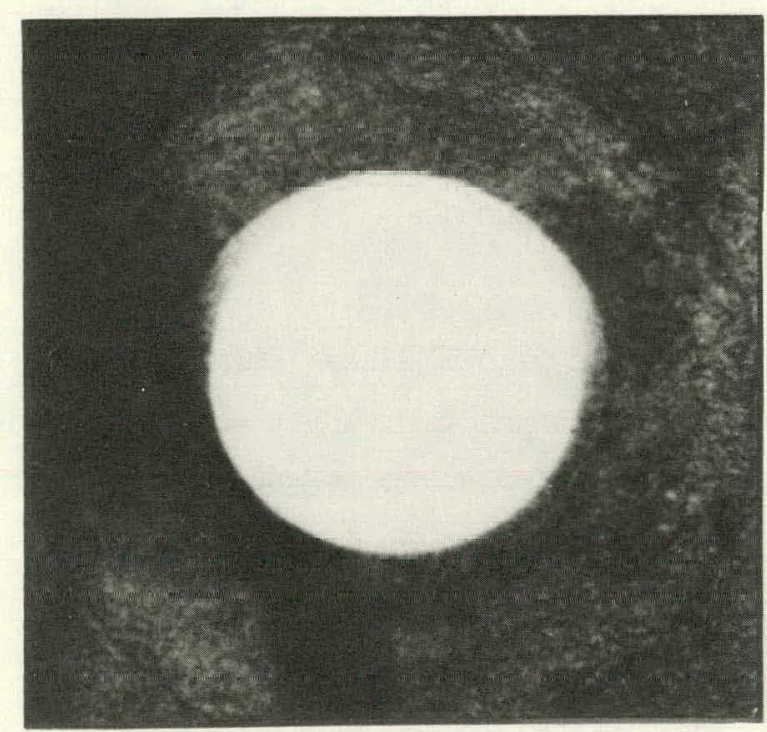

$158 \mathrm{hr}$

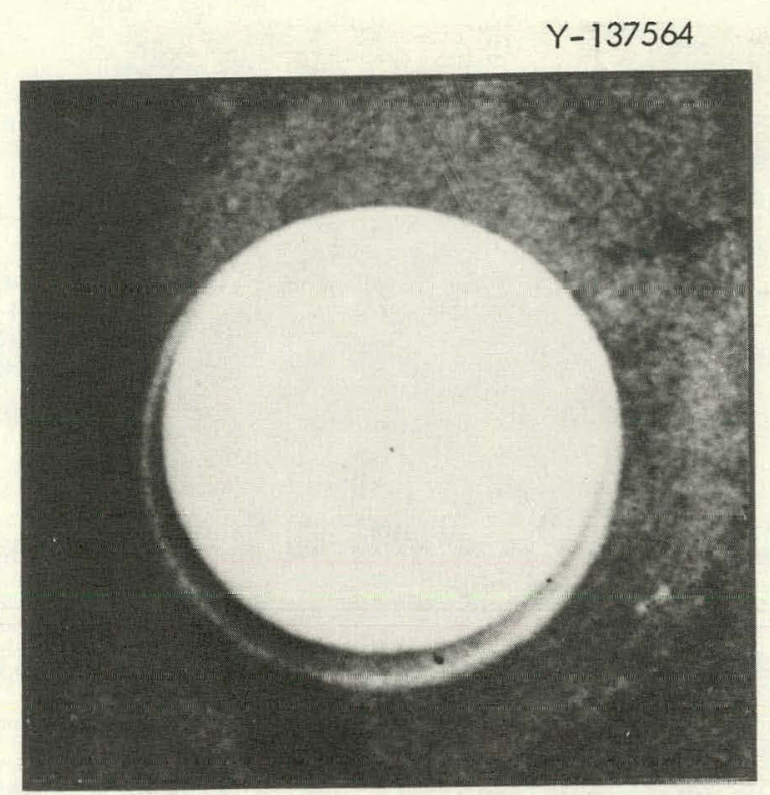

$73 \mathrm{hr}$

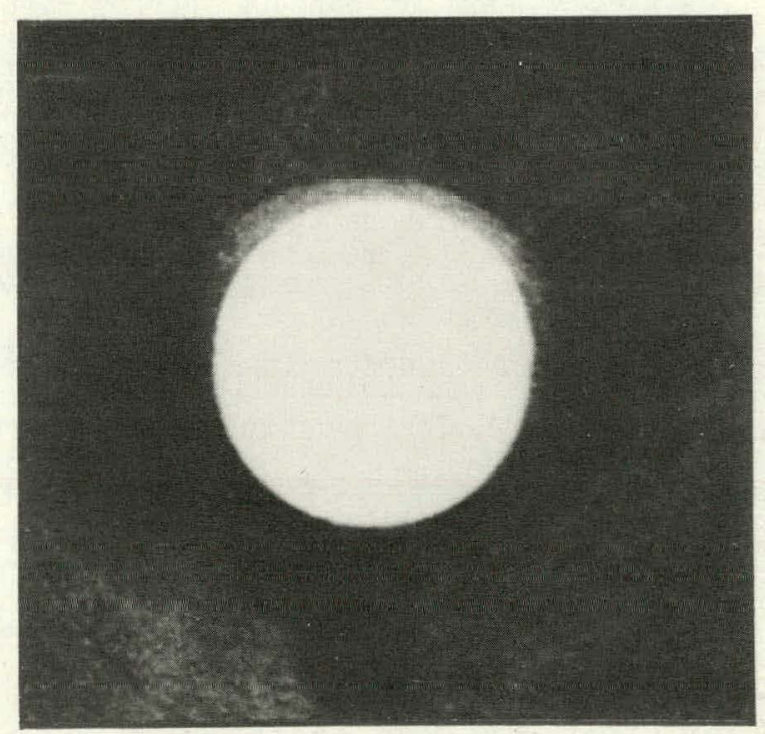

$582 \mathrm{hr}$

PARTICLE - BISO WAR UO $(31 \%)-\mathrm{UC}_{2}(69 \%)$

TFMPFRATI IRF $-1927^{\circ} \mathrm{C}$

TEMPERATURE GRADIENT $-278^{\circ} \mathrm{C} / \mathrm{cm}$

Fig. 9. Radiographs of a BISO-coated WAR ( $\left.31 \% \mathrm{UO}_{2}--69 \% \mathrm{UC}_{2}\right)$ particle heat-treated at $1927^{\circ} \mathrm{C}$ for various times. The cold side of the particle is a.t the top. The final volume of the uranium-containing kernel represents $\sim 30 \%$ of the original kernel volume, thus indicating that only $\mathrm{UO}_{2}$ is left in the particle. 


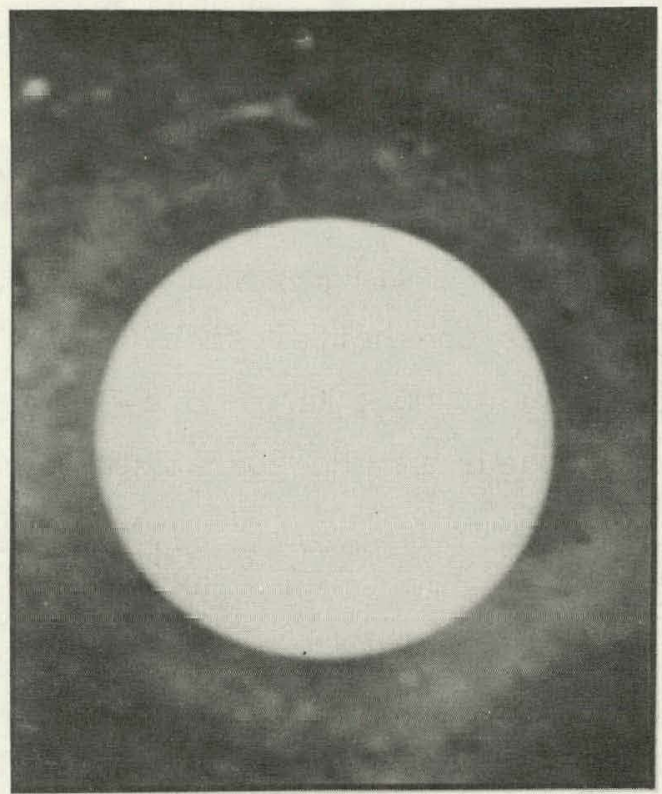

$\mathrm{O} \mathrm{hr}$

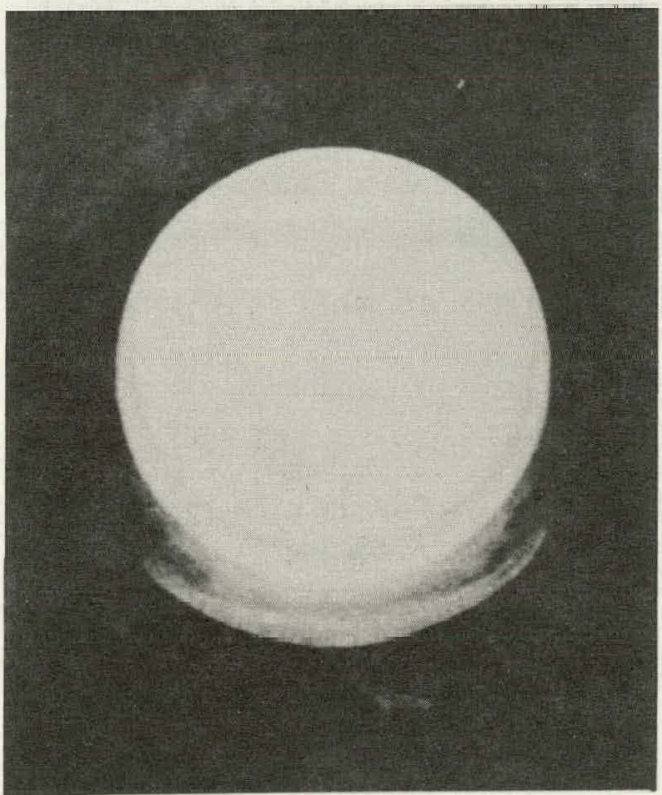

$75 \mathrm{hr}$

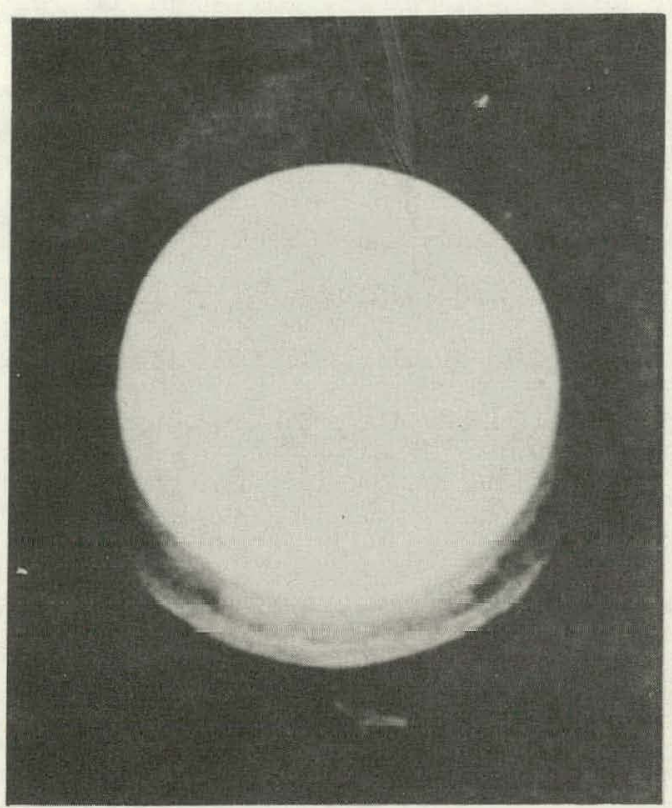

$53 \mathrm{hr}$

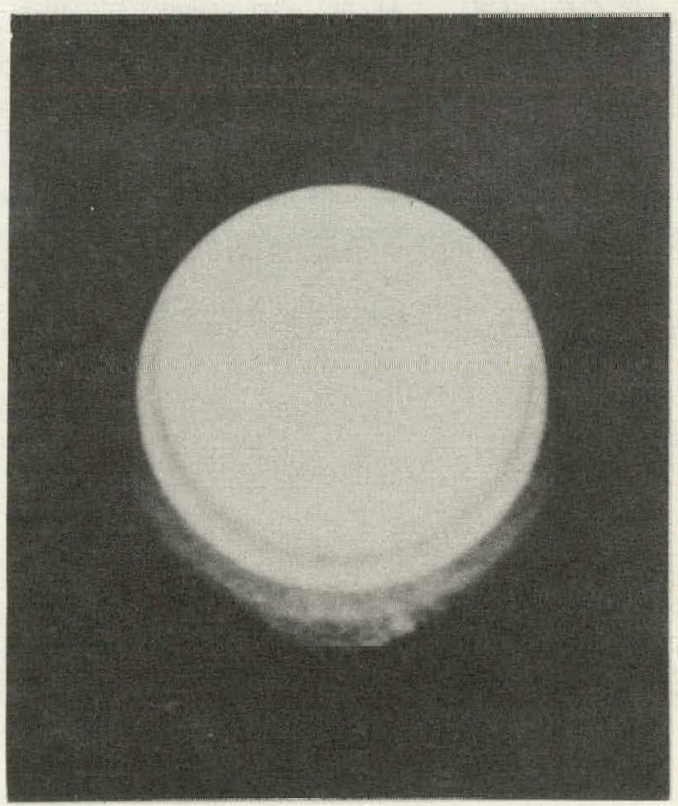

$127 \mathrm{hr}$

PARTICLE - BISO WAR UO $2(31 \%)-\mathrm{UC}_{2}(69 \%)$

TEMPERATURE - $1863^{\circ} \mathrm{C}$

TEMPERATURE GRADIENT $-278^{\circ} \mathrm{C} / \mathrm{cm}$

Fig. 10. Radiographs of a BISO-coated WAR (31\% $\left.\mathrm{UO}_{2}--6 \% \mathrm{UC}_{2}\right)$ particle heated at $1863^{\circ} \mathrm{C}$ in a $279^{\circ} \mathrm{C} / \mathrm{cm}$ gradient; the hot side is at the bottom. These radiographs demonstrate some of the characteristics of uranium Ioss (see text). 
kernel surface, as seen in Figs. 9 and 10. This portion is always oriented toward the cold side of the particle, probably as the result of local equilibrium for

$$
\mathrm{UO}_{2}+4 \mathrm{C} \rightarrow \mathrm{UC}_{2}+2 \mathrm{CO} \text {. }
$$

The $\mathrm{CO}$ pressure $\left(\mathrm{P}_{\mathrm{CO}}\right)$ is constant everywhere and would approximate that for the mean temperature. Consequently, $\mathrm{P}_{\mathrm{CO}}$ at the hotter side of the particle would be below that for the existence of $\mathrm{UO}_{2}$; thus more $\mathrm{UC}_{2}$ would be formed. The reverse process would occur at the cold side.

\section{ALNALYSLS UH' IIA'LA}

Quantitative representation of' the time-dependent data I'or the uranium loss is dependent on the proper selection of a mathematical model for the loss rate. The loss rate might be controlled either by steady-state diffusion of uranium through the ITI layer or by the rate of uranium evaporation at the surface of the $\mathrm{UC}_{2}$ crystallites in the WAR kernels. Solid-state diffusion within the $\mathrm{UC}_{2}$ crystallites is not a viable possibility for rate control because no such diffusion is necessary for the loss process; $\mathrm{UC}_{?}$ always exists at the receding $\mathrm{UC}_{2}-\mathrm{C}$ interface.

A model for rate control by uraniurn evaporation in the WAR $\mathrm{UC}_{2}$ kernels will be developed first. A general statement of the model is:

$$
\text { (U lost) }=(\text { rate constant })(\text { surface area })(\text { time })
$$

or

$$
\rho_{U} \frac{4 \pi}{3}\left(r_{0}^{3}-r_{f}^{3}\right)-k_{S}\left\{\left(\frac{S}{V}\right) \bar{V}\right\} t,
$$

in which $\rho_{T}$ is the density of uranium in the WAK kerne $\perp$, $r_{0}$ and $r_{f}$ are the initial and final kernel diameters, $k_{S}$ is the rate constant in ( $g$ of uranium) $\mathrm{cm}^{-2} \mathrm{sec}^{-1}, \mathrm{~S} / \mathrm{V}$ is the measured surface area per unit volume of WAR kernel in $\mathrm{cm}^{2} / \mathrm{cm}^{3}$, and $t$ is time in sec. The term $\bar{V}$ is the mean-valuetheorem average volume, in $\mathrm{cm}^{3}$, from which the uranium has vaporized over the entire experimental time. The volume of kernel from which the uranium is vaporizing during any time increment, $\Delta t_{i}$, is depicted in Fig. 11 ; here 


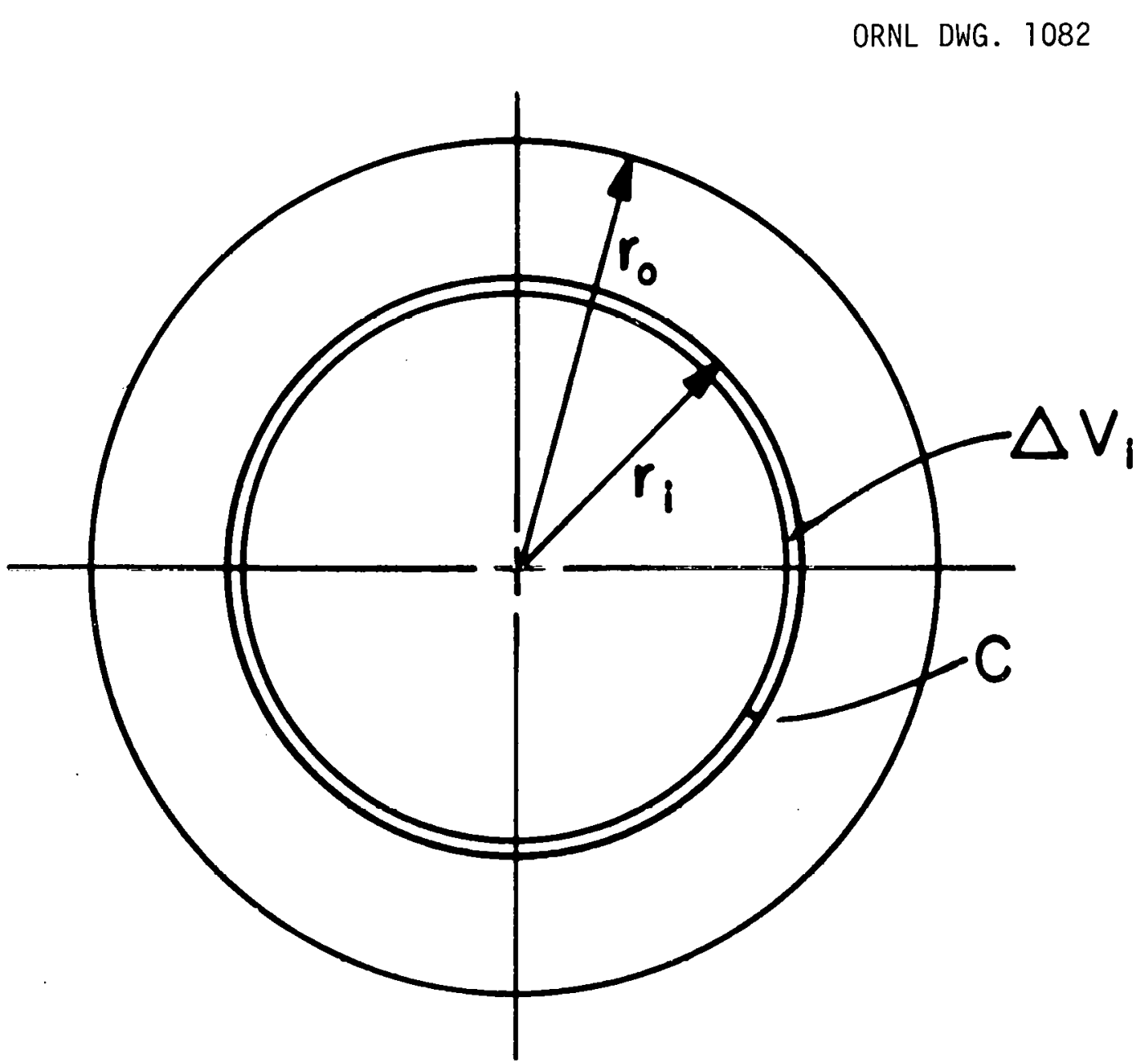

Fig. 11. Representation of a WAR $\mathrm{UC}_{2}$ kernel from which the uranium is released from the incremental volume $\Delta V_{i}$. 
$\mathrm{C}$ is the depth of the layer from which uranium is vaporizing. During any $\Delta t_{i}$, one obtains

$$
\Delta V_{i}=\frac{4 \pi}{3}\left[r_{i}^{3}-\left(r_{i}-c\right)^{3}\right] \text {. }
$$

Therefore, over all time, the mean-value theorem leads to:

$$
\begin{aligned}
\bar{V} & =\frac{4 \pi}{3} \frac{1}{\left(r_{0}-r_{f}\right)} \int_{r_{f}}^{r_{0}}\left[r^{3}-(r-c)^{3}\right] d r \\
& =\frac{1 / \pi}{3} \frac{1}{\left(r_{0}-r_{f}\right)}\left\{c\left(r_{0}^{3}+r_{f}^{3}\right)-\frac{3 C^{2}}{2}\left(r_{0}^{2}-r_{f}^{2}\right)+c^{3}\left(r_{0}-r_{f}\right)\right\} .
\end{aligned}
$$

Equation (6) can be substituted in kiq. (3) and $k_{S}$ solved for in terms of experimentally measured parameters. A simplified equation is achieved as long as $C$ is much smaller than $r_{f}$; in this case, one obtains:

$$
\rho_{U}\left(r_{0}^{3}-r_{f}^{3}\right) \approx k_{S} \frac{S}{V} t \frac{\left(r_{o}^{3}-r_{f}^{3}\right)}{\left(r_{o}-r_{f}\right)} C
$$

or

$$
r_{\sigma}-r_{f}=\frac{k_{S}}{\rho_{U}} \frac{\dot{s}}{V} C t \text {. }
$$

Thus, $\left(r_{0}-r_{f}\right)$ is proportional to $t$; since the experimental $r_{f}$ is generally observed to be linearly dependent on $t$, this is consistent with the premise that the rate-controlling mechanism is evaporation of uranium from the $\mathrm{UC}_{2}-$ containing WAR kernel.

In the casc of ratc control by cvaporation of uranium from tho surfaso of a fully dense $\mathrm{UC}_{\text {? }}$ kernel, the rate equation would be:

$$
\rho_{\mathrm{U}}^{i} \frac{4 \pi}{3}\left(r_{0}^{3}-r_{f}^{3}\right)=k_{S} \bar{S} t
$$

in which $\rho_{U}^{\prime}$ is the uranium density in the fully dense kernel and the average surface area of the shrinking kermel is:

$$
\bar{s}=4 \pi \frac{1}{r_{0}-r_{t}} \int_{r_{f}}^{r_{0}} r^{2} d r .
$$


Combination of the last two equations gives

$$
r_{o}-r_{f}=\frac{k_{S}}{\rho_{U}^{l}} t \text {. }
$$

For rate control by steady-state diffusion of uranium through the LTI layer, the uranium flux would be constant. Therefore, the volume of $\mathrm{UC}_{2}$ lost from the WAR kernel would be linearly dependent on time. In other words,

$$
\frac{4 \pi}{3} \rho_{U}\left(r_{0}^{3}-r_{f}^{3}\right)=k_{D} t,
$$

in which $k_{D}$ is the rate constant in ( $g$ of uranium) $\mathrm{cm}^{-2} \mathrm{sec}^{-1}$. [Equation (12) would also be applicable to rate control by a mechanism operating at an interface such as the ITI-buffer or LTI-matrix interfaces.] Calculation of $k_{D}$ at different heating times for the same particle sometimes resulted in constant $k_{D}$ values for all times. These data, therefore, did not lead to constant $\mathrm{k}_{\mathrm{S}}$ values from $\mathrm{Eq}$. (8) at all times. However, as mentioned earlier, Eq. (8) was more often followed and will be used to correlate all the data collected in this study.

The data analysis was accomplished with a simple procedure. The $r$-vs-t data for each particle were fitted to the linear equation $r=r_{0}-b t$ by least-squares techniques; both $r_{0}$ and $b$ were solved for. Thus, $r_{f}=r_{0}-$ $\mathrm{bt}_{\mathrm{f}}$ and Eq. (8) were used to give:

$$
\mathrm{k}_{\mathrm{S}}=\frac{\rho_{\mathrm{U}} \mathrm{b}}{\mathrm{c}\left(\frac{\mathrm{S}}{\mathrm{V}}\right)} .
$$

These values are given in Fig. $12 \mathrm{vs} 10^{4} / \mathrm{T}$ for the WAR data. The apparent activation energy for the data in Fig. 12 was found to be $97.9 \mathrm{kcal} / \mathrm{mole}$ (409 kJ/mole) by least-squares techniques. For the WAR $31 \% \mathrm{UO}_{2}-69 \% \mathrm{UC}_{2}$ data, the slope $b$ was determined as above from the initial $r_{f}$-vs-t values. The $\mathrm{k}_{\mathrm{S}}$ values, which are plotted in Fig. 13, can be seen to be nearly equivalent to the values in Fig. 12 .

Because the data of Figs. 12 and 13 overlap and the $\Delta H$ values are nearly the same, and because the volume of kernel remaining in the $31 \% \mathrm{UO}_{2}^{--}$ $6 \% \mathrm{UC}_{2}$ kernel was $30 \%$, we concluded that both types of particles show identical characteristics of $\mathrm{UC}_{2}$ loss. In other words, the uranium originated only with the $\mathrm{UC}_{2}$ fraction of the fuel. An average value of $\Delta H=90$ $\mathrm{kcal} / \mathrm{mole}$ ( $377 \mathrm{~kJ} / \mathrm{mole})$ was used in further calculations, and the average 


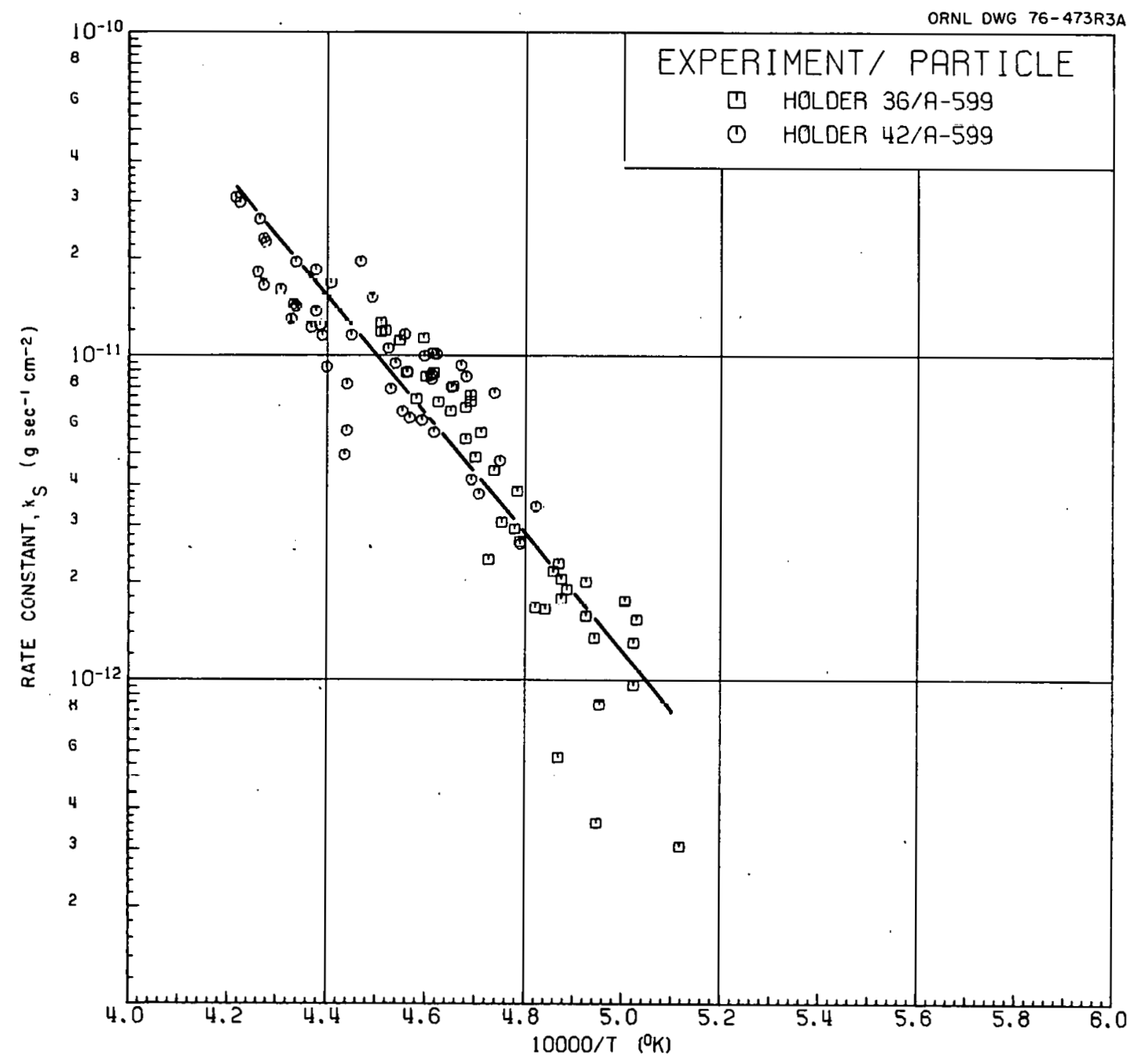

Fig. 12. Temperature characteristics of uranium vaporization from BISO-coated WAR $\mathrm{UC}_{2}$. The least-squares fit of these data is shown and can be represented by $k_{S}=0.0441 \exp (-97,300 / R T)$. 


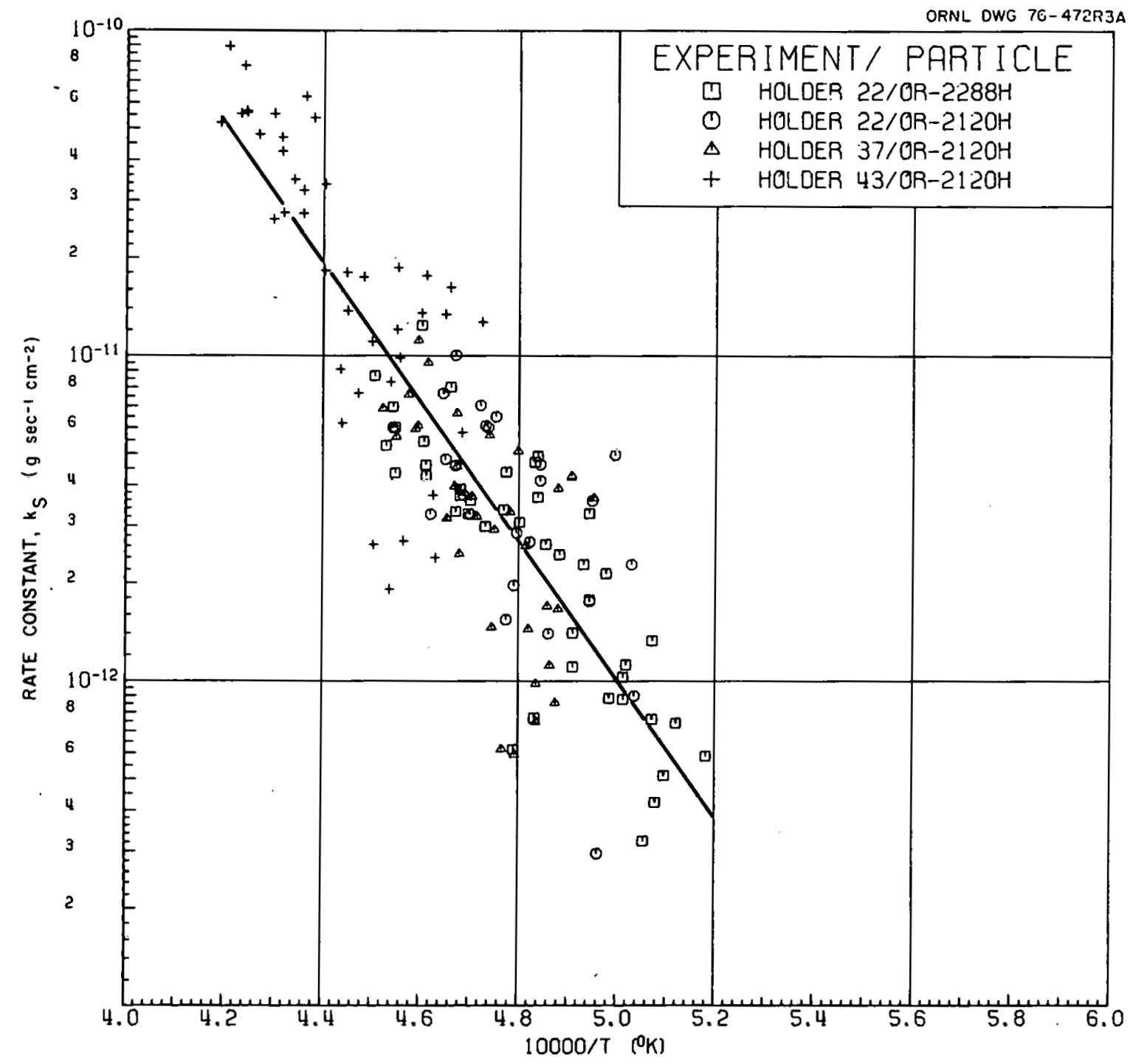

Fig. 13. Temperature characteristics of uranium vaporization from BISO-coated WAR $31 \% \mathrm{UO}_{2}--6 \% \mathrm{UC}_{2}$. The least-squares fit of these data is shown and can be represented by $k_{\mathrm{S}}=0.00124 \exp (-82,400 / \mathrm{RT})$. 
behavior of the data in Figs. 12 and 13 can be represented by the equation

$$
k_{S}=0.0075 \exp (-90,000 / R T) \text {. }
$$

\section{DISCUSSION}

We can offer a plausible explanation for the loss of $\mathrm{UC}_{2}$, but not $\mathrm{UO}_{2}$, from the kernels. The $\mathrm{UC}_{2}, \mathrm{UO}_{2}$, and carbon are in thermodynamic equilibrium and establish given gas pressures $P_{U}$ and $P_{C O}$ within the particle. As uranium is lost from the particle, the system attempts to maintain the equilibrium $\mathrm{P}_{U}$ via the reaction $\mathrm{UC}_{2} \rightarrow \mathrm{U}_{(\mathrm{g})}+2 \mathrm{C}$. Once the $\mathrm{UC}_{2}$ has completely disappeared, however, the equilibrium $\mathrm{UO}_{2}+2 \mathrm{C} \rightleftarrows \mathrm{U}(\mathrm{g})+2 \mathrm{CO}$ becomes established. For a short while, uranium is lost from the particle while $\mathrm{CO}$ is retained and $\mathrm{P}_{\mathrm{CO}}$ is increased within the particle. However, since the equilibrium constant $k_{e q}=P_{C O}^{2} P_{U}$ must be satisfied, $P_{U}$ is lowered drastically in the particle, thus reducing the uranium gradient across the particle coatings to the point where no significant uranium flux is possible. Note that intact irradiated oxide HTGR particles have been shown to retain CO, krypton, and xenon, with CO pressures orders of magnitude higher than those for the $\mathrm{UO}_{2}-\mathrm{UC}_{2}-\mathrm{C}-\mathrm{CO}$ equilibrium in the present particles. ${ }^{4-7}$

Observations of uranium loss from WAK $\mathrm{UC}_{2}$-containing particles, but not from fully dense $\mathrm{UC}_{2}$ particles, may be explained via Eqs. (8) and (II). The ratio of Eq. (8) to $\mathrm{Eq}$. (Il) gives, for identical $\mathrm{k}_{\mathrm{S}}$ and $\mathrm{t}$,

$$
\begin{aligned}
\frac{\left(r_{0}-r_{f}\right)_{\text {WAK }}}{\left(r_{0}-r_{f}\right)_{\text {denI }}} & =\frac{\rho_{U}}{\rho_{U}} \frac{3}{V} \mathrm{C} \\
& \approx \frac{11}{2.9} \times\left(120 \times 10^{\prime} \frac{\mathrm{om}^{2}}{\mathrm{~cm}^{3}}\right)\left(15 \times 10^{\mathrm{m}^{\prime}} \mathrm{cm}\right) \\
& \approx 4800 .
\end{aligned}
$$

Here $\mathrm{S} / \mathrm{V}$ was obtained from a measured $37 \mathrm{~m}^{2} / \mathrm{g}$ for WAR $\mathrm{UC}_{2}$ particles by multiplying the latter number by the density of the WAR particles. Therefore, in the time required for a WAR UC $U_{2}$ kernel to disappear $\left(r_{0}-r_{f} \approx\right.$ 
$150 \mu \mathrm{m})$, the radius of a fully dense kernel would decrease only $150 / 4800$ or $0.032 \mu \mathrm{m}$, an unobservable amount.

A recent report issued by the General Atomic Company ${ }^{8}$ summarizes the results of tests which are part of an extensive program directed toward the development of fuel for the first commercial HTGRs. These results have led to the selection of TRISO-coated $\mathrm{UC}_{2}$ as the reference fresh fissile particles and TRISO-coated WAR $\mathrm{UC}_{2}$ as the reference recycle fissile particles. Calculations were performed with the data published in this report to demonstrate the possible effect of uranium loss during the $\sim$ 4-year fuel life. These calculations were performed with Eqs. (8) and (14) at $t=!+$ years. From Eq. (8) the value of the product $(\mathrm{S} / \mathrm{V}) \mathrm{C} t / \mathrm{p}_{U}$ is $\sim\left(120 \times 10^{4}\right)\left(15 \times 10^{-4}\right)\left(1.26 \times 10^{8}\right) / 2.9$ or $7.9 \times 10^{10} \mathrm{~cm}^{3} \mathrm{sec}(\mathrm{g} \mathrm{U})^{-1}$. Thus $\left(r_{0}-r_{f}\right) /\left(7.9 \times 10^{10}\right)=k_{S}=0.0075 \exp (-90,000 / R T)$. This equation can be used along with the relation between radius and volume to calculate the uranium losses shown in Table 2 for a BISO-coated WAR UC 2 particle having $r_{0}=0.0165 \mathrm{~cm}$. A distribution of peak and time-average centerline temperatures of fuel in a planned commercial HTGR reactor was recently published in a report by Harmon and scott. 8 The data in the right-hand column of Table 2 were derived from Fig. 8 of that report. Clearly, the extent of uranium Ioss calculated here is inconsequential to the performance of the total TRISO-coated WAR $\mathrm{UC}_{2}$ fuel in a core at HTGR design temperatures. However, the results in Table 2 would seem to advise against exposure of $\mathrm{WAR}_{2} \mathrm{UC}_{2}$ fuel to higher temperatures in any future HTGR design; the uranium would probably permeate the entire particle within the SiC layer in a manner similar to that shown in Figs. 6-8 and subsequently lead to particle failure. 
Table 2. Calculated uranium loss in 4 years from 330- $\mu$ m-diam, BISO-coated $\mathrm{UC}_{2}$-containing WAR particles

\begin{tabular}{lcc}
\hline T $\left({ }^{\circ} \mathrm{C}\right)$ & Percent uranium lost & $\begin{array}{c}\text { Volume percent of fuel } \\
\text { whose time-average } \\
\text { temperature is } \geq \mathrm{T}^{\mathrm{b}}\end{array}$ \\
\hline 1590 & 99.9 & 0 \\
1500 & 60.0 & 0 \\
1400 & 16.0 & 0 \\
1350 & 7.2 & 0 \\
1300 & 3.0 & $\leq 0.5$ \\
1250 & 1.2 & $\leq 1$ \\
1200 & 0.43 & $\leq 10$ \\
1100 & 0.046 & $\leq 50$ \\
1000 & 0.0034 & $\leq 70$ \\
\hline
\end{tabular}

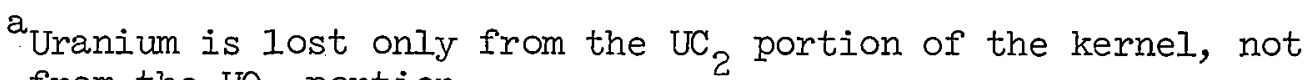
from the $\mathrm{UO}_{2}$ portion.

$\mathrm{b}_{\text {See Fig. } 8 \text { in ref. } 8 .}$

\section{CONCLUSTONS}

1. The present work has demonstrated a loss of uranium from the $\mathrm{UC}_{2}$ in either $\mathrm{UC}_{2}$ or $\mathrm{UC}_{2}-\mathrm{UO}_{2}$ WAR kernels contained in BISO-coated HTGR fuel particles. This loss is not dependent on a temperature gradient and occurs at easily measurable rates at $\mathrm{T} \geq 1650^{\circ} \mathrm{C}$ with an activation energy of $\sim 90 \mathrm{kcal} / \mathrm{mole}(377 \mathrm{~kJ} / \mathrm{mole})$.

2. TRISO particles containing $\mathrm{UC}_{2}$ or $\mathrm{UC}_{2}-\mathrm{UO}_{2}$ WAR kernels apparently retain the uranium; although uranium is lost from the kernels, a significant gain is observed in the uranium content of the buffer and ITI layers within the SiC layer.

3. The uranium loss from WAR kernels appears to be a consequence of the extensive surface area, $\sim 120 \times 10^{4} \mathrm{~cm}^{2} / \mathrm{cm}^{3}$. It apparently occurs across $a \sim 15-\mu m-w i d e$ interface that recedes toward the center of 
the WAR kernel. On the other hand, the surface area of fully dense $\mathrm{UC}_{2}$ kernels is only that of the geometrical surface area and is insufficient to permit observable uranium loss.

4. Uranium loss was not observed either from $W A R \mathrm{UO}_{2}$ kernels in BISO

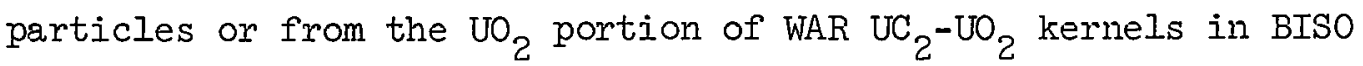
particles. A probable explanation for the loss of uranium from $\mathrm{UC}_{2}$, but not from $\mathrm{UO}_{2}$, has been developed from the thermodynamics of the $\mathrm{UO}_{2}-\mathrm{UC}_{2}-\mathrm{C}-\mathrm{CO}-\mathrm{U}(\mathrm{g})$ system.

5. Uranium loss from $\mathrm{UC}_{2}$-containing WAR kernels is calculated to be inconsequential under conditions expected to be encountered in an HTGR. All of the uranium would apparently be retained within the SiC coatings of the HTGR TRISO particles. It might accumulate to a small extent within the inner ITI layers of the highest-temperature particles in the HTGR core, but these particles constitute only a small fraction of the total fissile particles in the core.

6. The observed loss of uranium from BISO particles and the redistribution of uranium within TRISO particles would appear to preclude the use of $\mathrm{UC}_{2}$-containing WAR particles at temperatures higher than those of the present HTGR design.

\section{ACKNOWLEDGMENTS}

The authors wish to thank R. I. Beatty, G. W. Weber, W. J. Lackey, Jr., W. D. Mason, E. T. Rose, R. S. Crouse, and O. B. Cavin for their assistance with preparation and examination of fuel particles. Appreciation is also expressed to Martha Stewart, Betty Drake, and Christine Flanary for the editing and typing of this manuscript. 


\section{REFERENCES}

1. F. J. Homan, T. B. Lindemer, E. L. Long, Jr., T. N. Tiegs, and R. L. Beatty, "Stoichiometric Effects on Performance of HTGR Fuels from the U-C-O System," submitted to Nucl. Technol.

2. T. B. Lindemer and R. I. Pearson, Kernel Migration for HTGR Fuels from the Th-U-C-O-N System, ORNL/TM-5207 (April 1976); also accepted for publication in J. Am. Ceram. Soc.

3. G. W. Weber, R. L. Beally, und V. J. Terinery, "Frocessing and Composition Control of Weak-Acid Resin-Derived Fuel Microspheres," submitted to Nucl. Technol.

4. HTGR Fuels and Core Development Irogram, Quarterly Frogress Report for Period Ending Aug. 31, 1975, GA-A13592 (1975), pp. 98-113.

5. G. W. Horsley, G. J. Weldrick, J. A. Turribull, and R. Shipp, "Influence of Irradiation Temperature, Burnup, and Fuel Composition on Gas Pressure (Xe, $\mathrm{Kr}, \mathrm{CO}, \mathrm{CO}_{2}$ ) in Costed Particle Fuels, "J. Am. Ceram. Soc. 59, $1-4(1976)$.

6. T. B. Lindemer, "Measurement and Interpretation of $\mathrm{CO}$ and $\mathrm{Kr}+\mathrm{Xe} 1 \mathrm{II}$ Irradiated $\mathrm{ThO}_{2}$-Containing Particles," submitted to J. Am. Ceram. Soc.

7. L. W. Graham, "The Development and Pertormance of Hil'GR Core Materials," presented at the Gas-Cooled Reactor Information Meeting, Oak Ridge, Tenn., April 27-30, 1970; CONF-700401 (April 1970), pp. 494-517.

8. D. P. Harmon and C. B. Scott, Development and Irradiation Performance of LHTGR Fuel, GA-A13173 (October 1975). 
ORNL/TM-5552

Dist. Category UC-77

INTERNAL DISTRIBUTION

1. E. J. Allen

2. R. A. Bradley

3. A. J. Caputo

4. J.A. Carpenter

5. T. E. Cole

6. C. F. Coleman

7. J. H. Coobs

8. W. P. Fatherly

9. D. E. Ferguson

10. P. A. Haas

11. F. E. Harrington

12. C. C. Haws

13. F. J. Homan

14. J. D. Jenkins

15. D. R. Johnson

16-23. P. R. Kasten

24. W. J. Lackey

25-32. T. B. Lindemer

33. E. L. Long, Jr.

34. R. A. Lorenz

35. A. L. Lotts

36. J. C. Mailen

37. A. P. Malinauskas

38. W. J. McDowell

39. C. S. Morgan

40. M. T. Morgan

4I. F. H. Neill
42. K. J. Notz

43. A. R. Olsen

44. G. W. Parker

45. H. Postma

46-54. R. L. Pearson

55. W. H. Pechin

56. R. H. Rainey

57. J.M Robbins

58. J. H. Shaffer

59. J. W. Snider

60. Martha Stewart

61. V. J. Tennery

62. T. N. Tiegs

63. D. B. Trauger

64. V. C. A. Vaughen

65. G. W. Weber

65. J. R. Weir

67. R. P. Wichner

68. R. G. Wymer

69-70. Central Research Library

71. Document Reference Section

72. Laboratory Records, ORNL-RC

73-82. Laboratory Records

83. W. K. Davis (consultant)

84. E. I. Gaden, Jr. (consultant)

85. C. H. Ice (consultant)

86. R. B. Richards (consultant)

\section{EXTERIAL DISTRIBUTION}

87. Research and Technical Support Division, ERDA-ORO, P. O. Box E, Oak Ridge, Tn. 37830

88. Director, Reactor Division, ERDA-ORO, P. O. BOx E, Oak Ridge, Tn. 37830

89-90. Director, Division of Nuclear Fuel Cycle and Production, ERDA, Washington, D.C. 20545

91-92. Director, Div1sion of Reactor Kesearch and Development, ERDA, Washington, D.C. 20545

93-260. Given dislributiun as shown in TIV-4500 under category UC-77Gas-Cooled Reactor Technology 